\title{
ECONOMIC ACTIVITIES IN A MATRILINEAL CULTURE: A CASE STUDY OF THE TRAVELING MARCHANT IN MINANGKABAU VILLAGES IN INDONESIA
}

\author{
Silfia Hanani \& Delvi Wahyuni
}

Dosen STAIN Bukittinggi

\begin{abstract}
This paper seek to highlight economic activities in a matrilineal culture. Matrilineal cultural system has given enormous privileges for Minangkabau women. They have the right to manage the communal property. As the result, the practice of this culture promotes economic independence amongs Minangkabau people. There are three typical characteristics enclosed to this ethnic. First, Minangkabau people are keen practitioners of merantau (going overseas/leaving native places) tradition. Second, Islam is this ethnic official religion and the third, this ethnic practices matrilineal cultural system. This paper observes the activities of Minangkabau women who travel from one to other traditional markets as merchants which begins to gain popularity as a profession for Minangkabau women in the outset of Asian 1997 monetary crisis. Sikaladi was chosen as the research location of this study. Sikaladi is a jorong (a sub village) within the nagari of Pariangan The result show that, traveling as merchants can be promulgate as a semi-merantau activity. Those women leave their village on the basis and return in the same day. Currently, it has been noted that there are 69 woman traveling merchants in this jorong which means $40 \%$ of the overall women population of the jorong are traveling merchants. This situation suggests that these women involvement in economic activities has saved the course of their family from the disastrous storm of the 1997 monetary crisis. Further, it reduces the degree of poverty in this region. Most importantly, it also reduces the number of unemployment among women of productive age in Sikaladi.
\end{abstract}

Keywords: economic activity, matrilineal, minangkabau, travelling merchant

Abstrak: Makalah ini mencoba menyoroti aktivitas ekonomi dalan suatu budaya matrilineal. Sistem budaya matrilineal telah memberikan berbagai manfaat bagi wanita Minangkabau. Mereka memiliki hak untuk mengelola harta bersama. Sebagai hasilnya, praktek budaya ini meningkatkan kebebasan ekonomi diantara masyarakat Minangkabau. Terdapat tiga jenis karakteristik terkait dengan etnis ini. Pertama, orang Minangkabau sering mempraktekkan merantau. Kedua, Islam adalah agama resmi bagi etnis ini dan ketiga, etnis ini mempraktekkan budaya matrilineal. Makalah ini mengobservasi aktivitas wanita Minangkabau yang melakukan perjalanan dari satu pasar tradisional lain sebagai pedagang yang mulai mendapatkan popularitas sebagai profesi wanita Minangkabau pada awal krisis moneter di Asia tahun 1997. Sikaladi dipilih sebagai lokasi riset. Sikaladi adalah jorong dalam nagari Pariangan. Hasil penelitian menunjukkan bahwa melakukan perjalanan sebagai pedagang dapat dikatakan sebagai aktivitas semi merantau. Para wanita meninggalkan kampungnya dan kembali pada hari yang sama. Diketahui bahwa terdapat 69 wanita yang menjadi pedagang pada jorong ini yang berarti $40 \%$ dari keseluruhan populasi wanita adalah pedagang. Situasi ini menyatakan bahwa para wanita terlibat dalam aktivitas ekonomi telah menyelamatkan keluarga dari krisis moneter tahun 1997. Selain itu, aktivitas ini mengurangi kemiskinan di daerah ini. Yang terpenting adalah, aktivitas ini juga mengurangi jumlah pengangguran diantara wanita produktif di Sikaladi.

Kata K unci: aktivitas ekonomi, matrilineal, minangkabau, pedagang 


\section{INTRODUCTION}

Minangkabau people are indigenous to highlands of Indonesian West Sumatra province. They are one of the various ethnicities that make up Indonesia, a multiethnic modern nation-state in South East A sia. The 2005 statistics show that there were 3747 343 Minangkabauneses extolling them as West Sumatra's majority as well as predominant ethnic. In fact, they are the fourth majority ethnic in Indonesia. However, this is not the notion this paper seeks to highlight, yet their uniqueness from other ethnicities residing in West Sumatra in particular and Indonesia in a broader sense. Subsequently, the providing of the table below is seen as relevant both as an attempt to show West Sumatra's cultural plurality and, importantly, for the sake of statistic information.

Table 1. West Sumatra's population based on ethnicities

\begin{tabular}{lcc}
\hline \multicolumn{1}{c}{ Ethnicities } & Numbers & Percentage \\
\hline Minangkabau & 3747343 & 88.35 \\
Batak & 187656 & 4.42 \\
Javanese & 176023 & 4.15 \\
Mentawai & 54419 & 1.28 \\
Malay & 21654 & 0.51 \\
Chinese & 15029 & 0.35 \\
Sundanese & 10993 & 0.26 \\
Betawi & 672 & 0.02 \\
Madurese & 370 & 0.01 \\
Others & 27097 & 0.64 \\
Total & 4241256 & 100.00 \\
\hline
\end{tabular}

Source: West Sumatra in Numbers 2005

Having impinged on the notion of uniqueness, there are three typical characteristics enclosed to this ethnic. First, Minangkabau people are keen practitioners of merantau (going overseas/ leaving native places) tradition. Merantau is a tradition with the perspective of economic interest (Naim, 1979; Kato, 1989; Clamer, 2000). The feasible evident of this tradition is the existence of a large scale of Minangkabu diaspora in West Sumatra's neighboring provinces within the Island of Sumatra and in other far away provinces within this archipelagic country. Interestingly, the tradition of merantau is not confined within Indonesian territorial borders only but also exceeds to penetrate countries of Indonesian vicinity. Hence, it is no wonder that Minangkabau diaspora can also be found in the Malay Peninsula. In addition, they are well-known, especially for the perantau (the diaspora), as resilient businessmen (read merchants). Second, Islam is this ethnic official religion (Hamka, 1978; Kahn, 1980; Diradjo, 1987; Navis, 1988; Naim, 1999). By right, once a person born as a Minangkabaunese, she/ he is a Muslim. Most importantly, once she/ he renounces their Islamic religion, they lose their ethnicity. In other words, in terms of customary law, they are not adknowledged as Minangkabau people anymore. Third, this ethnic practices matrilineal cultural system (Mansoer, 1979; Kato, 1988; Amir, 1999). To put it in another way, children belong to their mother dan where family name and ancestral house are passed down from mother to daughter. Ideally, within this matrilineal cultural system women enjoy enormous privilege in having role in decision making regarding family or clan matters, as well as granted authority to manage harato pusako (customary property) which thus is highly relevant to their role and involvement in economic activities. 
Silfia Hanani: Economic Activities in a Matrilineal Culture: A Case Study oof the Travelling Merchant in...

However, this paper will only focus on the involvement of Minangkabau women in economic activities in a more current context. This paper observes the activities of Minangkabau women who travel from one to other traditional markets as merchants which begins to gain popularity as a profession for Minangkabau women in the outset of Asian 1997 monetary crisis which hit Indonesia most severely. Through the course of this paper, it will be exposed some reasons behind these women's involvement in market economy and its immediate impact to their by birth privileges as Minangkabau women. Most importantly, this paper will show how this world largest matrilineal ethnic engage and respond to contemporary world trends.

Sikaladi waschosen astheresearch location ofthisstudyfor, ononehand,writers'familiarity with the area. On the other hand, Sikaladi is an epitome of villages in Minangkabau land of which social dynamic has been radically changed by the involvement of their woman population as traveling merchants. Sikaladi is a village within Tanah Datar regency, West Sumatra. The 2006 statistical record shows that this area had 9.913 populations. Sikaladi is famous for its cool climate and fertile soil. Moreover, Sikaladi happens to be in a strategic junction of transportation which enables its population to commute to and fro its vicinity as well as to trave as merchants.

Geographically, Sikaladi is located on a plateau in the foot of Mount Merapi, the highest mount in West Sumatra. Due to this geographical benevolence, there is no wonder that most of the population earn their living from agricultural activities. Before 1997, Sikaladi was an agricultural centre for Tanah
Datar regency. As the result, Sikaladi was able to drench the markets' demand for vegetable in Batusangkar, the capital of Tanah Datar regency.

Historically, Sikaladi is the neighbor of Pariangan which is considered as the oldest nagari in Minangkabau land. Pariangan is the initial nagari for the Minangkabau people. In a later development, other villages were founded to accommodate the population growth. A group of villages in Minangkabau is called as nagari. A sub-village in a nagari is called as jorong. Hence, Sikaladi is a jorong within the nagari of Pariangan (Mansour, 1970; Naim, 1984; Kato, 1988; Navis,1988; Hanani 2002).

The 1997 monetary crisis has a disastrous effect on an agricultural region exemplified by Sikaladi. The price of fertilizer skyrocketed and thegovernment quit subsidizing the prize of the fertilizer which left farmers in a difficult condition. As a result, it has become difficult to totally count on agricultural activities to support the family expenditure. In Sikaladi, the most interesting effect of this crisis is seen in the radical change of occupation pattern of Sikaladi women. Formerly, most of them were housewives. Their main economic activities are limited to attending their land when the season to plant the paddy has come or helping their husbands in their vegetable patches. In other words, they are not the primary breadwinner. Currently, most of Silakadi women travel from one to another traditional market as traveling merchants and take this new activity as their profession. 


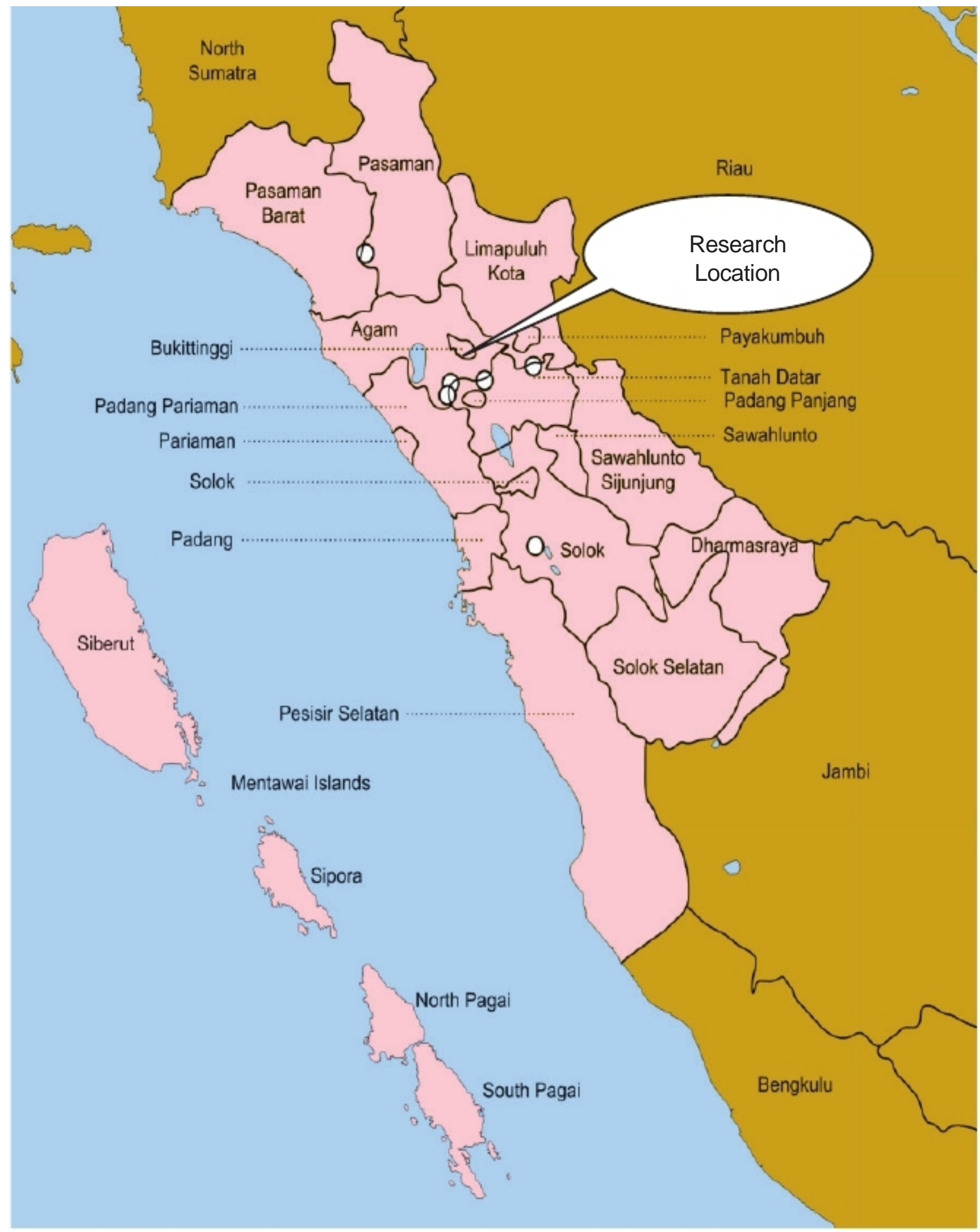

Map: Province of West Sumatra and Research Location. 
Silfia Hanani: Economic Activities in a Matrilineal Culture: A Case Study oof the Travelling Merchant in...

\section{DESCRIPTION}

The impact of the 1997 economic crisis is two folds on the Minangkabau women, to be particular Sikaladi women. First, they are pushed from domestic domain into public sphere. In this case, women are needed more than ever to support the family income. Interestingly, the crisis also paves the way for the Sikaladi women to engage with new means of financial earning. According to Aryunis and Hanani (2002) since the 1997 crisis Minangkabau women began to leave agricultural sector to participate in trading sector which makes them actively involve in economic market. To put in another way, the very same crisis is such a blessing in disguised since they become independent economically more than ever. In other words, for Sikaladi women, the economic crisis is not a prolonged dilemma. Second, by professing as traveling merchants these women are on the continuous process to preserve their matrilineal culture. In this sense, their economic independence allows them to keep privileges granted to them by the customary law. Therefore, they are able to retain a strong bargaining position in political and economic sense.

This paper argues that this relatively new profession can also be seen as a kind of cultural breakthrough. Traditionally, traveling trading was an exclusive occupation for men. Traveling as merchants can be promulgated as a semi-merantau activity. Minangkabau men leave their native village for a few days to travel as merchants to various traditional markets. After collecting sufficient amount of money, they travel back to their village. Subsequently, when their saving is running low, these men travel again to trade (Naim, 1987; Kato, 1988). It means their base is still in their nativeplacecompared to the 'full-time' or 'permanent' perantau who has adopted foreign land as their new base even their new home. The breakthrough in question is by professing as traveling merchants, these women step into the male dominated merantau tradition. As a result, they arealso important determinants of Minangkabau cultural identity which one of them is merantau tradition.

However, these women's semi-merantau practicehastheir own distinctivecharacteristic. Those women leave their village on the basis and return in the same day. They travel to traditional markets in accordance to hari balai (market day) of that particular market. Every traditional market in West Sumatra as well as in Indonesia has its own scheduled market days or hari balai. Hence, within a week there are seven traditional markets of which those women can travel to. This kind of activity is called by manggaleh kaliliang ka pasa-pasa (literally: traveling from market to market to trade)

A typical daily time table for these female traveling merchants is they leave for the market before dawn or before azan subuh (a call for prayer at dawn) in groups boarding oto cateran (public means of transportation such as buses, mini buses, cars). Some of them also use the service of oto langganan (they routinely hire someone with a car or a bus to take them to their destination and bring them back home on daily basis). At dusk, also in group, they trave back home. Salapeh maghrib or approximately at $19 \mathrm{pm}$. is the earliest time for them to get home. 


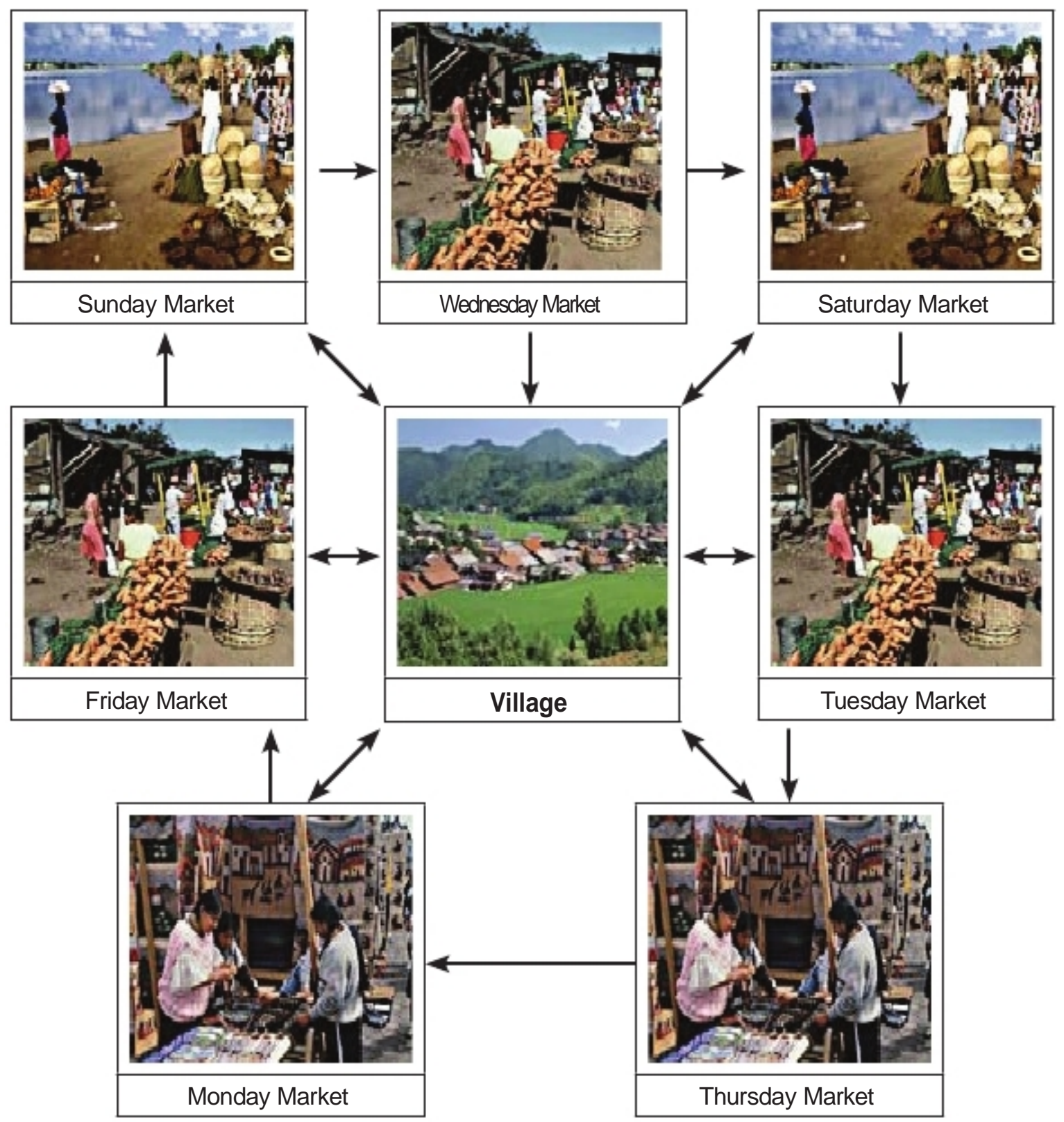

Information of Symbol

$\longrightarrow$ Continue

$\longleftrightarrow$ Return

Figura: Berdagang Keliling Market to Market

This diagram shows the daily mobility pattern of the woman traveling merchant

Interestingly, their merchandises show their agricultural root since most of them trade vegetable and fruits. Some of them sell the agricultural products from their own land.
However, they al so purchasethemerchandises from other farmers and traders and re-sell them. Other popular merchandisesaresoybean products such as tofu (bean curd) and tempe (fermented soybean cake). Sometimes, some of them are the producers and at the same time the retailers. There are also some women who 
do not have their own land work as fulltime marketing staff of this soybean based industry.

It is important to inform that in each market they travel to, they have their own stand of outlet yet they are not permanent. In other words, if they fail to appear in themarket in a particular day, other merchants can easily occupy their business place. The way they find their business place is also interesting since they only have to seek for vacant space in the market and used it as their outlet. If they occupy that place frequently, that tempek manggaleh (outlet/stand) is automatically considered as their business area. Usually, due to this 'invisible' law, no other merchants will dare to trespass one's outlet lest they are not present. Hence, prolonged absence in a market can cost them their outlet since other merchants are eligible to claim that place.

They recognize several marketing systems. First, they sell their merchandise by weighing them in kilogram system. They simply call it as kilo. Second, thereisthesystem of onggok (heaps, stacks or piles). Meaning the measurement of their goods and the price are based on that onggok. The third system is the system of kabek or bunch especially for vegetables. These three systems are called generally as manjua enceran (retailed selling).

The profit from this activity is highly depended on two factors. First, thesemerchants will gain moreif thepriceof their merchandises is hiking. In this logic their profit margin is good so that they can earn more. This period is usually called as musim harago naiak (literally: season of hiking prices). Second, particular events likereligious holidays and periods such spay day timedeterminetheir earning. Usually, few days before the start of the fasting month or Ramadhan, they will preserve extra stock to fulfill the increasing demand of vegetables and other staple food anticipating the fasting ritual. The same situation will prevail in few days before Id Fitri (the celebration by the end of Ramadhan) and Id Adha (feast of the sacrifice). Interestingly, the price of some vegetables like French bean, tomato, and chili are hardly in control since they are highly in demand because families need them to prepare popular Id Fitri's cuisines. It is north discussing since this situation the strong hold of Islam in this culture.

At the peak time of musim harago naik, traders can gain more than 150.000 IDR (\$ 15). In their capacity as petty merchants, this amount is outstanding so that they can saveor use it to better their living condition. Usually, once enough money is available, they will repair the old house; even build a new house; and purchase various (sometimes luxurious) household equipments. Interestingly, there is a kind of competition amongst these traders in terms of repairing their houses of buying various household equipments. Hence, it is a common view to see permanent and well preserved houses in the jorong of Sikaladi after the 1997 crisis.

This situation suggests that these women involvement in economic activities has saved the course of their family from the disastrous storm of the 1997 monetary crisis which wreaks havoc Indonesian economy. Further, it reduces the degree of poverty in this region. Mostimportantly, it al so reduces thenumber of unemployment among women of productive age in Sikaladi. Currently, it has been noted that there are 69 woman traveling merchants in this jorong which means $40 \%$ of the overall women population of the jorong are traveling merchants. 


\section{Reverse sexually labor division}

This new occupation for Sikaladi women has changed the pattern sexually labor division. Formerly, occupations for women as constituted by both customs and social constructions are bound to domestic sphere. Meanwhile, men are demanded to earn for the family in the public sphere. A nother factor contributing to the changing of occupation pattern for Minangkabau women is the shift from extended family to nuclear family which is entailed by the demise of the practice of passing down the tanah/harta pusako tinggi (customary property) to the women of the family. In fact, this notion is argued as having negative impact on Minangkabau women since women are denied their right to manage the property (most of them is the form of land) and make use of them economically. As a consequence, it curbs their economic independence which 'forces' them to totally count on their husbands financially. Hence, this kind of situation weakens their political bargaining position despite they still live within the framework of matrilineal culture. Therefore, theprofession astraveling merchant for these women is argued as their way to engage with the degradation of one of the core element of their culture which costs them their traditional privilege.

In accordance to Minagkabau customary law, the family's asset is managed communally. There are two kinds of family's assets constituted by the customary law. The first one is the harato kaum or communal property which is commonly called as harato pusako tinggi in the form of land. This land is passed down to the oldest woman of the clan and managed communally. Importantly, the profit gained from the land is used to satisfy that clan's interest. Usually, that land is used for agricultural activities where women are in charge of the land. The customary law has constituted that it is forbidden to sell the land for it has something to do with the clan's prosperity. However, the change of the local governmental system and the passing of the Agrarian Laws in 1988 have caused the disruption to the legacy of the communal land. People begin to divide it as individual property. Worse, for the land has become individual belonging, people begin to sell the customary land. The second family asset is the harato pusako rendah which is the asset of the nuclear family. In other words, this property is earned together by a couple of husband and wife. This land is used in accordance to the family's interest.

The harato pusako rendah or the nuclear family's land is commonly managed by the husband asthebread winner of the family. The wife's role is to assist the husband when it is needed. Most of the time, the wifeis at hometo raise the children and does household chores. Hence, the labor division in the nuclear family is clear enough. Thanks to the crisis, totally dependent to agricultural sector becoming difficult for the price of the fertilizer climbs highly into the degree of unaffordable. Worse, at the same time, the price of the agricultural products jumps down as it is not able to cover the cost of the production. As explained before women leave their 'sphere' to trade. Subsequently, household chores are trusted to theoldest daughter of thefamily if thereis any. If the children are too young to do the chores, the husband will take over the responsibility. To put it in another way, the husbands turn to be urang rumahan (those who stay at home). Thus, reverse sexually labor division is an immediate effect of this economic activity. 
Silfia Hanani: Economic Activities in a Matrilineal Culture: A Case Study oof the Travelling Merchant in...

This change of occupation pattern suggests the social change where there is a reverse pattern of appreciation. When women are in the domestic sphere, they become men's 'worshippers'. In other words, the wives should beready with the best servicethey have whenever their husbands return from their work. However, with their current occupation, the husbands are expected to serve the wives when they return from the market. However this study observes that this change does not trigger domestic conflicts. It is quitesurprising for it has been prescribed socially that the responsibility to take care of the children is given to women and the responsibility in terms of economy is granted to men. In other words, this change which is contradictory to common social constructions does not affect the family's harmony.

In this context, it is proven that Karl Marx's economic determinism is at work. The sufficient earning from the activity of traveling trading which is done by the women does not raise family conflicts in spite of the changing in terms of occupation pattern which is not in line with the common social constructions.

\section{Changes on the M anagement of the Family's Economic Asset}

Before traveling trading becomes a kind of trend in this region, the family's economic assets such as land are managed by both husband and wife. Occasionally, they will have someone does particular tasks regarding the land. However, when the wives become fulltime traveling merchant and the husbands do most of chores at home, the land is subsequently managed by someone hired by the family. Hence, the husband is not the dominant manager anymore for thefamily has hired some one to work for the land as well as testifying that agricultural activities is not popular anymore in families whose mother or daughters work as traveling merchant.

Interestingly, for the family which has several adult children, land is still a prominent source of living. Due to the availability of the men power which comprises of the father and children, that particular family works their own land without relaying to hired workers. The role of the women of the family which comprises of themother or thedaughteristosell the harvest in the market. It is not necessarily that the mother or the daughters are full-time traveling merchants but with this ability they know how and where to market their harvest that they can gain more profit compared to those who just count on the middle men to market their harvest. Yet, most of the time, these women finally chose to becomefull-time traveling merchant because it is seen as more promising compared to breaking their back bone attending and cultivating their land.

\section{The emergence of mechanic social solidarity}

In a society where most of its member travels routinely, as in the case of the woman traveling merchants in the jorong of Sikaladi, there will be changes in the pattern of social solidarity. The first thing that is responsible for this change is the significant length of the time the (woman) traveling traders leave their family and native village. Every day, from dawn to dusk they will be away from home which denies them maximum chance to communicate and interact with their neighbors. Due to traveling daily (seven days a week) it is difficult for them to keep making many social interactions and alert to current happenings in their neighborhood. Consequently, the organic social solidarity is waning away and mechanic social solidarity 
will emergeinstead. For example, before being active as traveling merchants, women have enormous time to interact with their society member. Most of the time, they participate in many social functions in their neighborhood. It is apparently supportiveto the social dynamic which practices the pattern of organic social solidarity. However, thing changes when those women's time is spent mostly in the market.

The immediate impact of the mechanic social solidarity is the decline of the tradition of batandang (literally: visiting neighbors' houses). Batandang facilitates the women to communicate with their neighbors and to acquire information about the latest news or gossips in the neighborhood. The communication which occurs in the procession of batandang is called as maota (to have a chat). The topic of the chatting it self has no restrain. Most importantly, maota itself is the discussion forum for them.

The tradition of maota is not the privilege of the women since men also practice it. Usually, the men will visit a lapau (a coffee shop) to have a cup of coffee for a while before going to their rice field or farm. At this moment, the tradition of maota is a common view. They discuss about many things from family matters until political matters even global issues like wars or world sport evens. Uniquely, this kind of gathering in the lapau becomes a forum to socializethegovernment's policy in their region. However, this tradition begins to wanealong with their wives' activity as traveling merchants. The husbands now replace the wives' responsibility to take care of the children if the family's children are still young. In the morning, they have to deal with their children who want to go school or feed the toddler children that deny them the opportunity to have a cup of coffee and to have a long winding chat in the lapau.

The waning of this kind of communication tradition affects the already established organic social solidarity pattern. According to Durkheim and Tonnis (Jonson, 1987) the interaction pattern which is practiced in the society is an important factor to the existence of solidarity in a society. Moreover, communication is a kind of interaction which is responsible to bearing a strong bonding amongst themember of the society. Thechange in the tradition of communication has a great role in transforming the organic solidarity pattern to the mechanic solidarity pattern as evident isthewaning of thetradition of mutual aid within the society.

\section{The adaptation of city lifestyle by the village dwellers}

Trading brings more prosperity to the economy of the family. It enables the family to have a life style. It is evident when the newly emerging 'rich' families begin to build a 'better' house in a sense of wood houses are replaced with stone and plastered houses and the adoption of 'modern' and western architecture for their houses. For an instance, formerly, the kitchen and the bathroom are detached from the main building. Currently, those parts have been integrated into one building.

The change of the architecture of the house into a 'modern' one is entailed with the purchasing of more modern house hold equipments as well. Cooking using wood to make fire in a hearth has become obsolete. Kerosene or gas stoves hit the trends. The usage of kitchen cabinet to store the cooking equipments has also become a new trend. A television set is a must in the living room of 
Silfia Hanani: Economic Activities in a Matrilineal Culture: A Case Study oof the Travelling Merchant in...

the family house. As the result, the household equipments advertisements storm into the family's domain which generates the consumerism lifestyle. A refrigerator which is formerly not a necessity has become a new demand for an instance. These new and modern kitchen utensils and household equipments become the kind of barometer for the family's prestige. Consequently, the profit gained from trading is spent carelessly on these stuffs instead of investing it for a better future. Besides, wearing precious jewel ries for the women and following the current trend in terms of fashion also suggest the family's prestige. It is noted that people has left the tradition of sitting on the floor while having break fast, lunch or dinner to a favor of a set of modern dining table. Interestingly, they are also affected by the worldwide campaigned advertisements of being beauty means being slim. Previously, a woman is regarded as beautiful if she is voluptuous and with curve. Currently, that local beautiful notion has been replaced since teenagers begin to practice diet.

In this context it can be understood that there is a significant relationship between the economy of the family with their life style. Their new profession as traveling merchants in fact has prospered that family which is responsible for the change of the life style. In this case, Karl Marx is right when he predicted that economy is the changing agent of tradition. The ownership of economic facilities has brought a new life style for a group of people. The new lifestyle unavoidably brings the culture of consumerism. Yet, it uplifts the prestige amongst the society members. As the result, they choose to be consumerist to keep their prestige. Thus, the city lifestyle has been adopted by the village dwellers.

\section{The new awareness toward the importance of education}

Education in Indonesia is a kind luxury enjoyed by those who have strong economic power. It iscommonly know that theeducation cost in this country is comparatively high and for some is unaffordable. The 1997crisis affects the perspective of the Sikaladi people in two ways. First, the crisis forces children (most of them are girls) to stop going to school. Hence, during the crisis, girls who cannot continue their study assist their mothers in the market. In this sense, it cannot be denied that the involvement of this productive work force into traveling merchant activities has helped to overcome the problem of high rate unemployment as the direct result of the 1997 economic crisis. Indonesian Central Bureau of Statistics has noted in 1997 that there were 4, 18 million of unemployed persons, 6, 03 million (1999), 5, 81 million (2000), 8.005 million (2001), 9, 13 million (2002), 11, 35 million (2003). Then, the statistics show that in 2001 there were 144,033 million people of productive age, 98,182 million work forces, 90,807 million employed population, 8,005 million open unemployed people, 6,010 million semi-forced employed people, 24,422 million semi-voluntarily unemployed people. In 2002 the statistics show 148,730 million people of productive age, 100,779 million work forces, 91,647 million employed population, 9,132 million open unemployed people, and 28,869 million semi-forced unemployed people. As a conclusion, because of the crisis, people perspective on education can be regarded as negative.

However, people's perception towards education turns into a more positive mood. It is argued that since their mothers professing as traveling merchant, many families has 
experienced economic some betterment so that children can continue their education. Crucially, education is seen in a more glamorous perspective. The ability to send the children to attend higher educational institutions like university either public or private one has become the symbol of prosperity and prestige. They believe that attending universities will help their children to land in high prestige jobs with generous salary. This economic betterment in the jorong of Sikaladi is seen as the main factor that accelerates the improvement in the jorong's education sector. Referring to the statistics in 2005, there were 12 children who could not continue their study, yet in 2006 the number reduced into 4 children. Thus, it is clear that along with the newly acquired prosperity, the family's quality of education is significantly improved.

\section{Conclusion}

Matrilineal cultural system has given enormous privileges for Minangkabau women. They are give the right to manage the communal property. As the result, the practie of thisculturepromotseconomicindependence amongs Minangkabau people. In this sense, the matrilineal cultural system which is practiced by Minangkabau people is not just a cultural rhetoric but a real application. However, the 1960 Agrarian Law has made the harato pusako tinggi comes to their extinction and at the same time Minangkabau women lose their cultural privileges. Importantly, these women cannot enjoy the economic independence they have previously. Minangkabau woman are becoming financially dependent to their husband. In other words, matrilianial cultural practice is only an empty slogan since women in this culture live in a typical patrilineal system. Interestingly, the 1997 monetary crisis seems to blow the wind of 'radical' change in terms of Minangkabau woman occupation. Despite without the support of land, their involvement in economic activities such as becoming travelling merchant has made them once again independent in terms of economy. Therefore, Minangkabau woman, against all odds, are seen as the preserver of the spirit of matrilineal cultural system which the core identity of their ethnic.

\section{REFERENCE}

Aryunis and Hanani, S. (2002) Perubahan Pola Kerja Perempuan Minangkabau (Padang: Padang Press)

Clamer, J. (2002) Diaspora and Identity The Sociology of Culture in Southeast Asia (Malaysia: Pelanduk Publication)

Dirajo, S. (1987) Curaian adat alam Minangkabau (Bukittinggi: CV. Pustaka Indonesia)

Hanani, S.(2000) Surau Aset Lokal Yang Tercecer (Bandung: PT. Humaniora)

Jhonson, D. P. (1987) Teori Sosiologi Klasik dan Modren (Jakarta: PT. Gramedia)

Kahn, J. S. (1980) Minangkabau Social Formation: Indonesian Peasent and the World-economy (Sydney: Cambridge University Press).

Kato, T. (1989) Nasab ibu dan merantau tradisi Minangkabau yang bertarusan di Minangkabau (Kuala Lumpur: Dewan Bahasa dan Pustaka)

Mansoer. (1970) Sejarah Minangkabau Jakarta: Bahtera)

Naim, M. (1984) Merantau Pola Migrasi Suku Minangkabau (Yogyakarta: Gajah Mada University Press)

Navis, AA. (1988) Alam Takambang Jadi Guru (Jakarta: Aksara)

Pemda Sumatera Barat. (2005) West Sumatra in Numbers 2005 (Padang: Pemda Sumbar) 